\title{
CLINICAL TRIAL OF FAZADINIUM BROMIDE (FAZADON)
}

\author{
C.E. Famewo
}

\begin{abstract}
Fifty healthy Nigerian surgical patients were given fazadinium bromide at a dose level of $10 \mathrm{mg} \cdot \mathrm{kg}^{-1}$ while 30 other similar patients received $1.5 \mathrm{mg} \cdot \mathrm{kg}^{-1}$. Anaesthesia was induced with either thiopentone or alfathesin. Tracheal intubation was satisfactorily accomplished after a mean of 55 seconds with the $1 \mathrm{mg} \cdot \mathrm{kg}^{-1}$ dose and a mean of 32 seconds with the $1.5 \mathrm{mg} \cdot \mathrm{kg}^{-1}$ dose. Duration of action of fazadinium $1 \mathrm{mg} \cdot \mathrm{kg}^{-1}$ was a mean of $42 \mathrm{~min}$ (range 30 to $50 \mathrm{~min}$ ) while the mean for $1.5 \mathrm{mg} \cdot \mathrm{kg}^{-1}$ was $55 \mathrm{~min}$ (range 45 to $70 \mathrm{~min}$ ). There was no significant difference between the thiopentone and alfathesin induction groups. Reversibility with neostigmine was excellent. Whereas the $1 \mathrm{mg} \cdot \mathrm{kg}^{-1}$ dose was satisfactory for normal regular intubation, the $1.5 \mathrm{mg} \cdot \mathrm{kg}^{-1}$ dose is recommended for "crash" intubation. The administration of fazadinium was associated with a stable blood pressure and moderate sinus tachycerdia. No other side effects were seen.
\end{abstract}

Key Words: Neuromuscular Relaxants, Fazadinium, Neostigmine

IN 1851 CLAUDE BERNARD established the site of action of curare by a series of experiments on the spinal frog, but not until 1941 was curare introduced into clinical anaesthesia by Griffith and Johnson' of Montreal. Since then many other muscle relaxants have been introduced in an attempt to overcome the shortcomings of those already in clinical use. Fazadinium bromide (AH8165) was introduced into clinical practice by B.R. Simpson, et $a l .^{2}$ It is a new non-depolarising muscle relaxant with the chemical structure shown in Figure 1. The molecule has two identical halves, each with a quarternary ammonium group, linked by a nitrogen chain. The molecular weight is about 604. Most of the fazadinium is excreted unchanged in the urine but some hepatic excretion may also occur. It is supplied in $5 \mathrm{ml}$ ampoules, each $\mathrm{ml}$ containing $15 \mathrm{mg}$ of fazadinium bromide. It is yellow in colour, isotonic in solution and has a characteristic (rather unpleasant) smell of sulphide. The odour is due to the thioglycerol used to stabilise it in solution. It has an acidic $\mathrm{pH}$ of 4 , which precludes its mixture in the same syringe with alkaline anaesthetics like thiopentone. Plasma protein binding is less than 10 per cent.

This study was done to evaluate some aspects of the clinical use of fazadinium, viz:

(1) Speed and ease of tracheal intubation.

C.E. Famewo, M.B., B.S. Dip. Anaes. (Toronto) F.R.C.P.(C), Department of Anaesthesia, University of Ibadan and University College Hospital, Ibadan, Nigeria.

\section{CHEMICAL SIRUCTURE OF FAZADON}<smiles></smiles>

FIGURE 1

(2) Duration of action of the initial intubation dose.

(3) Ease of reversibility with neostigmine.

(4) Side effects.

\section{Materials and METHOD}

Initially, 50 Nigerian patients presenting for elective surgical operations were studied at a dose level of $1 \mathrm{mg} \cdot \mathrm{kg}^{-1}$ body weight. Subsequently, a similar group of 30 patients were studied at a dose level of $1.5 \mathrm{mg} \cdot \mathrm{kg}^{-1}$ body weight. The age, sex, and weight distribution are shown in Table I. Informed consent was obtained from the patients.

Patients were premedicated with pethidine given by the intramuscular route about 1 hour before induction while atropine $0.6 \mathrm{mg}$ was 
TABLE I

Sex, Age and Weight Distribution of Patients

\begin{tabular}{lcccccc}
\hline \hline $\begin{array}{c}\text { Dose of } \\
\text { Fazadinium }\end{array}$ & $\begin{array}{c}\text { Number of } \\
\text { Patients }\end{array}$ & \multicolumn{2}{c}{ Sex } & & $\begin{array}{c}\text { Age in years } \\
\text { Mean and } \\
\text { Range }\end{array}$ & $\begin{array}{c}\text { Weight in kg } \\
\text { Mean and range }\end{array}$ \\
\cline { 2 - 4 } $1.0 \mathrm{mg} \cdot \mathrm{kg}^{-1}$ & 50 & 30 & 20 & & $\begin{array}{c}36 \\
(22-55)\end{array}$ & $\begin{array}{c}64 \\
(58-80) \\
60 \\
(50-76)\end{array}$ \\
$1.5 \mathrm{mg} \cdot \mathrm{kg}^{-1}$ & 30 & 18 & 12 & & $\begin{array}{c}35 \\
(20-53)\end{array}$ & $(50-76)$ \\
\hline
\end{tabular}

TABLE II

INDUCTION AGENTS USED

\begin{tabular}{lccc}
\hline \hline $\begin{array}{c}\text { Dose of } \\
\text { Fazadinium }\end{array}$ & Thiopentone & Alfathesin & $\begin{array}{c}\text { Total number of } \\
\text { patients }\end{array}$ \\
\cline { 2 - 4 } $1.0 \mathrm{mg} \cdot \mathrm{kg}^{-1}$ & 24 & 26 & 50 \\
$1.5 \mathrm{mg} \cdot \mathrm{kg}^{-1}$ & 16 & 14 & 30 \\
\hline
\end{tabular}

given intravenously just before induction of anaesthesia. Anaesthesia was induced with either thiopentone $4 \mathrm{mg} \cdot \mathrm{kg}^{-1}$ or alfathesin $0.075 \mathrm{ml} \cdot \mathrm{kg}^{-1}$ in a random fashion, given through a vein on the dorsum of the hand or distal forearm.

When indicated by diaphragmatic or gross musculo-skeletal movement, the second dose of fazadinium was given. This amounted to 25 per cent of the initial dose in the $1 \mathrm{mg} \cdot \mathrm{kg}^{-1}$ group or 15 per cent of the initial dose in the $1.5 \mathrm{mg} \cdot \mathrm{kg}^{-1}$ group. However, no dose was given within the 15 minutes before the end of operation. Anaesthesia was maintained with nitrous oxide/oxygen and intermittent doses of fentanyl. Ventilation was controlled mechanically using a tidal volume of $10 \mathrm{ml} / \mathrm{kg}$ at a rate of 12 per minute. Blood pressure and heart rate were monitored, and the patients were observed for any side-effects

Other observations and measurements included the following:

(1) Time from end of injection of fazadinium to end of tracheal intubation.

(2) Condition at intubation, graded according to the scheme described by Lund and Stovner. ${ }^{3}$

(3) Duration of action of the initial dose of fazadinium.

(4) Ease of reversibility with intravenous neostigmine $2.5 \mathrm{mg}$, graded as:

(i) Very Good, (ii) Good, (iii) Just Fair. Clinical criteria such as tidal exchange, good hand grip or head lifting were used as appropriate.
TABLE III

Tracheal intubation Times

(End of Fazadinium Injection to End of Intubation)

Mean Intubation times (secs.) $\pm \mathrm{SE}$

\begin{tabular}{lcc}
\cline { 2 - 3 } $\begin{array}{c}\text { Dose of } \\
\text { Fazadinium }\end{array}$ & $\begin{array}{c}\text { Thiopentone } \\
\text { induction }\end{array}$ & $\begin{array}{c}\text { Alfathesin } \\
\text { induction }\end{array}$ \\
\hline $1.0 \mathrm{mg} \cdot \mathrm{kg}^{-1}$ & $53 \pm 3$ & $55 \pm 4$ \\
$1.5 \mathrm{mg} \cdot \mathrm{kg}^{-1}$ & $32 \pm 2$ & $31 \pm 1.5$ \\
\hline
\end{tabular}

\section{Results}

The intubation times are shown in Table III. Intubation was usually achieved satisfactorily after a mean of 55 seconds with the $1 \mathrm{mg} \cdot \mathrm{kg}^{-1}$ dose or 32 seconds with the $1.5 \mathrm{mg} \cdot \mathrm{kg}^{-1}$ dose. Intubation conditions are shown in Table IV. It is apparent that the patients in the $1.5 \mathrm{mg} \cdot \mathrm{kg}^{-1}$ dose group rate higher than those in the $1.0 \mathrm{mg} \cdot \mathrm{kg}^{-1}$ dose group $(p<.001)$.

The duration of action of the initial dose of $1.0 \mathrm{mg} \cdot \mathrm{kg}^{-1}$ ranged between 30 and 55 minutes with a mean of 42 minutes while with $1.5 \mathrm{mg} \cdot \mathrm{kg}^{-1}$ the duration ranged between 45 and 70 minutes with a mean of 55 minutes. There was no significant difference between the thiopentone and alfathesin induction groups. Reversibility with neostigmine $2.5 \mathrm{mg}$ was graded "Very Good" in all the patients. 
TABLE IV

Intubation CONditions Using Lund \& Stovner Grading*

\begin{tabular}{|c|c|c|c|c|}
\hline \multirow{2}{*}{$\begin{array}{c}\text { Dose of } \\
\text { Fazadinium }\end{array}$} & \multicolumn{3}{|c|}{ Grading of Intubation } & \multirow{2}{*}{$\begin{array}{c}\text { Total number of } \\
\text { patients }\end{array}$} \\
\hline & 1 & 2 & 3 & \\
\hline $1.0 \mathrm{mg} \cdot \mathrm{kg}^{-1}$ & $\begin{array}{c}8 \\
(16 \%)\end{array}$ & $\begin{array}{c}30 \\
(60 \%)\end{array}$ & $\begin{array}{c}12 \\
(24 \%)\end{array}$ & $\begin{array}{c}50 \\
(100 \%)\end{array}$ \\
\hline $1.5 \mathrm{mg} \cdot \mathrm{kg}^{-1}$ & $\begin{array}{l}2 \\
(6.7 \%)\end{array}$ & $\begin{array}{c}10 \\
(33.3 \%)\end{array}$ & $\begin{array}{c}18 \\
(60 \%)\end{array}$ & $\begin{array}{c}30 \\
(100 \%)\end{array}$ \\
\hline
\end{tabular}

*Grade 3-Excellent: Well separated cords, not moving; no bucking on the tube. Grade 2-Satisfactory: Slight movement of cords when touched; slight bucking. Grade l-Fair: Condition less favourable than in the previous category but permitting intubation.

TABLE $Y$

Changes in Blood Pressure and Heart Rate (Mean \pm SE)

\begin{tabular}{lcccc}
\hline & Pre-induction & $\begin{array}{c}\text { Post-induction } \\
\text { but pre-Fazadon }\end{array}$ & $\begin{array}{c}\text { Post-Fezedon } \\
\text { but pre-intubation }\end{array}$ & Post-intubation \\
\hline $\begin{array}{c}\text { Systolic B.P. } \\
\text { (mm Hg) }\end{array}$ & $119 \pm 3.1$ & $117 \pm 2.8$ & $120 \pm 2.5$ & $124 \pm 4.1$ \\
$\begin{array}{c}\text { Heart Rate } \\
\text { (per min) }\end{array}$ & $86 \pm 2.5$ & $88 \pm 2.9$ & $110 \pm 4.2^{*}$ & $112 \pm 5.3^{*}$ \\
\hline
\end{tabular}

$* P<0.01$ (Student $t$ test).

\section{Cardiovascular effects}

The changes in the blood pressure and pulse rate before and after administration of fazadinium are shown in Table $\mathrm{V}$. There was no significant change in the blood pressure but there was a significant increase in the heart rate following the administration of fazadinium $(p<0.01)$. There was no associated irregularity in the rhythm.

\section{Side Effects}

None of the patients demonstrated any clinical features of histamine release such as urticaria or bronchospasm.

\section{DISCUSSION}

Suxemethonium, a depolarising muscle relaxant, is the usual choice of relaxant for rapid intubation in emergency situations where the patient may have a full stomach. However, its undesirable effects include muscle fasciculations and increased intragastric pressure ${ }^{4}$ which may predispose to aspiration, as well as post-operative pains. ${ }^{5}$ The shifts in potassium associated with suxamethonium can be dangerous in patients with extensive soft tissue trauma and burns. To avoid these problems a new non-depolarising muscle relaxant, fazadinium, has been evaluated.
It produced better conditions for rapid intubation at a dose level of $1.5 \mathrm{mg} \cdot \mathrm{kg}^{-1}$ than at the $1.0 \mathrm{mg} \cdot \mathrm{kg}^{-1}$ dose (Tables III \& IV); hence $1.5 \mathrm{mg} \cdot \mathrm{kg}^{-1}$ is recommended for "crash" intubation. This is in contrast to Mehta, et al. ${ }^{9}$ who found no difference between these two dose levels and reported intubation times of 27 and 26 seconds for the $1.0 \mathrm{mg} \cdot \mathrm{kg}^{-1}$ and $1.5 \mathrm{mg} \cdot \mathrm{kg}^{-1}$ doses respectively. Coleman, et al. ${ }^{10}$ on the other hand, reported a mean intubation time of 31 seconds after a $1.5 \mathrm{mg} \cdot \mathrm{kg}^{-1}$ dose. This is similar to the results obtained in this study. Whereas $1.0 \mathrm{mg} \cdot \mathrm{kg}^{-1}$ is satisfactory for normal regular intubation, it is suggested that $1.5 \mathrm{mg} \cdot \mathrm{kg}^{-1}$ should be used whenever "crash" intubation is desired, as in cases of "full stomach".

The mean duration of 42 minutes for the $1.0 \mathrm{mg} \cdot \mathrm{kg}^{-1}$ dose and 55 minutes for the 1.5 $\mathrm{mg} \cdot \mathrm{kg}^{-1}$ dose fall within the range reported by other investigators. ${ }^{1,12}$ The duration seems to be dose dependent. The different methods of determining the duration of action of fazadinium, however, make valid comparison difficult. For instance, recovery measured by twitch response or electromyography does not consistently relate to clinical signs of recovery. Acid-base changes, according to the study by Coleman, et al.,${ }^{13}$ do not seem to have a significant effect upon the inten- 
sity or duration of neuromuscular blockade by fazadinium in patients who were made acidotic or alkalotic by respiratory changes.

Reversibility with intravenous neostigmine $2.5 \mathrm{mg}$ was clinically very good in all the patients in this study and none needed additional doses of neostigmine.

With regard to the cardiovascular effects, it is difficult to separate the effects of induction of anaesthesia, laryngoscopy, tracheal intubation and controlled ventilation from those effects purely due to fazadinium. In this study the blood pressure was essentially stable but there was a statistically significant change in heart rate. However, the degree of tachycardia was moderate and was not associated with any abnormalities of rhythm.

In conclusion, fazadinium is a good alternative to suxamethonium in situations where the latter poses problems. Other than the moderate sinus tachycardia, no significant side-effects were observed with the clinical use of fazadinium.

\section{ACKNOWLEDGEMENT}

I wish to thank Professor J.A.O. Magbagbeola, Head, Department of Anaesthesia, University College Hospital, Ibadan for his encouragement and Mr. Daniel Adeniyi Adefila for his secretarial assistance.

Fazadinium (trade name FAZADON) was supplied by courtesy of Glaxo Nigeria Limited.

\section{REFERENCES}

I. Griffith, H.R. \& Johnson, G.E. The use of curare in general anaesthesia. Anesthesiology 3:418 (1942).
2. Simpson, B.R., Savage, T.M., Foley, E.I., Ross, L.A., Strumin, L., Walton, B., MaxWELL, M.O. \& Harris, D.M. Anazobisarylimidazo-pyridium derivative, a rapidly acting non-depolarising muscle relaxant. Lancet $l: 516$ (1972).

3. LUND, J. \& Stovner, J. Dose response curves for Tubocurarine, Alcuronium and Pancuronium. Acta Anacsth. Scand. Suppl. 37: 238 (1970).

4. RoE, R.B. The effect of Suxamethonium on intragastric pressure. Anaesthesia 17: 179 (1962).

5. ChurChill-Davidson, H.C. Suxamethonium and muscle pains. Brit. Med. J. l: 74 (1954).

6. Mazze, R.I., Escue, H.M. \& Houston, J.B. Hyperkalaemia and cardiovascular collapse following administration of succinylcholine to the traumatized patient. Anesthesiology 31: 540-547 (1969).

7. Schaner, P.J., Brown, R.L., Kirksey, T., et al. Succinylcholine induced hyperkalaemia in burned patients. Anaesth. and Analg. 48: 764-770 (1969).

8. Blogg, C.E., Savage, T.M., Simpson, J.C., Rose, L.A. \& Simpson, B.R. A new muscle relaxant-AH 8165. Proc. Roy. Soc. Med. 66: 1023 (1973).

9. Mehta, S., Lewin, K. \& Fidler, K. Rapid intubation with Fazadinium and Suxamethonium. Canad. Anaesth. Soc. J. 24: 270 (1977).

10. Coleman, A.J., O'Brien, A., Downing, J.W., Jeal, D.W., Mayes, D.G., \& Leary, W.P. H 8165, A new non-depolarising muscle relaxant. Anaesthesia 28: 262 (1973).

11. Arora, M.V., Clarke, R.S.J., Dundee, J.W. \& Moore, J. Initial Clinical experience with AH 8165 D., a new rapidly acting non-depolarising muscle relaxant. Anaesthesia 28: 188 (1973).

12. Inoue, K., ERdmann, W., Stegbaner, H.P. \& FrEY, R. Klinische erfahrungen mit einem neuen muskelrelaxans Fazadon. Munch. Med. Wschr. 116: 1839 (1974)

13. Coleman, A.J., Walling, P.T., Downing, J.W. \& BeEs, L.T. The effect of carbon dioxide on the ncuromuscular and haemodynamic effects of $\mathrm{AH}$ 8165 , a new non-depolarising muscle relaxant. $\mathrm{Br}$. J. Anaesth. 47: 365 (1975).

\section{RÉSUMÉ}

Cinquante patients nigériens en bonne santé programmés pour la chirurgie ont reçu du bromure de fazadinium à la dose de $1 \mathrm{mg} \cdot \mathrm{kg}^{-1}$ alors que 30 autres patients supplémentaires ont reçu $1.5 \mathrm{mg} \cdot \mathrm{kg}^{-1}$. L'anesthésie a été mise en marche avec du thiopental ou de l'alfatésine. On a réussi l'intubation trachéale de façon satisfaisante après 55 secondes en moyenne avec la dose de $1 \mathrm{mg} \cdot \mathrm{kg}^{-1}$ et en 32 secondes avec la dose de $1.5 \mathrm{mg} \cdot \mathrm{kg}^{-1}$. La durée d'action du fazadinium à la dose de $1 \mathrm{mg} \cdot \mathrm{kg}^{-1}$ était en moyenne de 42 minutes (entre 30 et 50 minutes) alors que la durée moyenne pour la dose de $1.5 \mathrm{mg} \cdot \mathrm{kg}^{-1}$ était de 55 minutes (entre 45 et 70 minutes). Il n'y a pas eu de différence significative entre le groupe alfatésine et le groupe thiopental. On recommande la dose de $1.0 \mathrm{mg} \cdot \mathrm{kg}^{-1}$ pour l'intubation régulière alors qu'il est préférable d'utiliser la dose de $1.5 \mathrm{mg} \cdot \mathrm{kg}^{-1}$ pour l'intubation en catastrophe. Le renversement par la néostigmine a été jugé comme très bonne dans tous les cas. 